\title{
Floristic Composition, Vegetation Structures and Physiognomy of a Typical Guinea Savannah: A Case Study of Minna-Bida Road, Niger State
}

\author{
Daudu Oladipupo Abdulazeez Yusuf, Abubakar Abdulhakeem*, Dangana Mohammed Chatta \\ Department of Biological Sciences, Federal University of Technology, Minna, Nigeria \\ Email address: \\ abuakim2007@gmail.com (A. Abdulhakeem), dauduoladipupoyusuf@yahoo.com (D. O. A. Yusuf) \\ ${ }^{*}$ Corresponding author

\section{To cite this article:} \\ Daudu Oladipupo Abdulazeez Yusuf, Abubakar Abdulhakeem, Dangana Mohammed Chatta. Floristic Composition, Vegetation Structures \\ and Physiognomy of a Typical Guinea Savannah: A Case Study of Minna-Bida Road, Niger State. International Journal of Biochemistry, \\ Biophysics \& Molecular Biology. Vol. 2, No. 4, 2017, pp. 22-30. doi: 10.11648/j.ijbbmb.20170204.11
}

Received: August 16, 2017; Accepted: September 1, 2017; Published: September 30, 2017

\begin{abstract}
Vegetation studies was undertaken to assess the floristic composition of Minna-Bida road of Niger State. The project area, i.e. Minna-Bida Vegetation, is a vegetation study cutting across five local government areas, Bosso, Chanchaga, Minna, Katcha and Bida local government areas of Niger State; this region lies in the Guinea Savannah. Transect and quadrat sampling methods were used to determine the vegetation cover of the study areas; in addition, GPS was used to take the coordinates of each of the sampling sites. The result showed that a total of 38 plant species belonging to 21 families were recorded in transects surveyed and comprising of both woody and herbaceous plant species. The species floristic indices of these communities is hereby presented in Table 4 . Sixteen (16) species representing about $42 \%$ of the censored species were trees, ten (10) species representing about $26 \%$ are shrubs, whereas, twelve (12) species representing about $32 \%$ were herbs. The five most abundant species across the proposed project areas at the Minna-Bida community include: Hyptis suaveolens (739 individuals), Daniella oliveri (58 individuals), Vitellaria paradoxa (35 individuals), Mangifera indica (14 individuals), and Ageratum conyzoides (160 individuals). However, five of the species that had the least abundance are: Vitex doniana (1 individual), Prosopis africana (3), Senna sp (7 individuals), Nymphaea lotus (5 individuals), Khaya senegalensis (2 individuals). The IUCN status of most of the plant species encountered during the study showed that they can be broadly classified into two conservation status; most of the plants encountered are Data Deficient (DD), were as few of them are Vulnerable (V). Sheanut tree, Utricularia, Afzelia africana, and Mahogany are vulnerable, whereas, most of the other plants are either data deficient or least concerned. It is therefore concluded that Minna-Bida road represents a typical guinea savannah due to the composition of plants encountered. The floristic composition of the project area is highly diverse in species even over a seemingly homogenous area.
\end{abstract}

Keywords: Vegetation, Floristic Composition, Guinea Savannah, Abundance

\section{Introduction}

The guinea savannah biome is characterized by heterogeneity in the physiognomy and spatial structure of the vegetation [1]; where a mosaic with high and low-cover patches is created by the varied proportion of woody plants interspersed in a grass matrix [2]. Vegetation structure generally considers the composition of plant community in terms of specific morphological characteristics while composition is the floristic assemblage of plant species that characterize the vegetation [3]. The coexistence and spatially heterogeneous distribution of different life form layers of woody and herbaceous vegetation [4] may be responsible for low mapping accuracies of savannah land cover classes, as shown in several comparative assessment studies [5]. Thus, the properties of the mix of woody and herbaceous vegetation can be very important in understanding the complex information on the relation between land cover and the properties of each class or physiographic unit [6]. Along this practical assessment of wood as resources came a 
reappraisal of what can be broadly called the cultural value of living trees, woods and herbs along the study areas. People enjoy having trees around them because they shelter from wind, rain, and scorching sunshine. Their grace of forms and seasonal renewal of fresh green foliage often enlivened by gay flowers, provide welcome scenery, and offset the hard lines of man-made buildings. They also provide habitats for remarkable wild flowers, beasts and birds that would perish if the woods disappeared [7].

Knowledge on structural characteristics of vegetation is highly demanded both locally and globally. On the global scale, more detailed and standardized data on biomass and vegetation structure of vegetation units are required [8] in order to obtain comprehensive global vegetation maps. On the local scale, information on structural characteristics of vegetation as well as standardized inventories of these properties are important for detailed structural descriptions of both the tree and the herb layer with respect to the stratified vegetation types, and secondly, to compare the vegetation types in terms of structural parameters. Sanford and Isichei [9] elaborated a classification for West African savannah based on physiognomic and structural characteristics giving detailed values for stem density and girth distribution of the tree layer. On local and regional scale, some studies used floristic data for classification [10].

The impacts of a construction of highway could be considerable on the flora and vegetation. Bradshaw and Chadwick [11] in their essay on land restoration noted that "a well-landscaped road can be a considerable advantage to the country side while a bad one is a disaster". Thus, there is need to look into mitigation of impacts and the enhancement of the natural features of the vegetation and the total environment in order to make this road an asset. Several invasive species of plants may infiltrate habitats using roads. Information available showed that roads can facilitate invasions because those plants face less competition from plants in a newly cleared area.

The project area, i.e. Minna-Bida vegetation, cutting across five local government areas, Bosso, Chanchaga, Minna, Katcha and Bida local government areas of Niger State; this region lies in the Guinea Savannah. The vegetation is a typical Northern Guinea Savannah types, characterized by presence of trees, shrubs and herbaceous flora. It is interesting to note that, due to the nature of these areas, the plant components of the vegetation that remains during the dry season are most the trees and shrubs and some drought tolerant herbaceous flora. This will, undoubtedly, affect the composition and population of animal communities during the dry and raining seasons.

\section{Materials and Methods}

\subsection{Vegetation Sampling Methods}

Transect and quadrat sampling methods were used to determine the vegetation cover of the study areas. A transect is a straight line across an expanse of ground along which ecological measurements are taken, continuously or at regular intervals. Quadrat, on the other hands, is a frame that is laid down to mark out a specific area of the community to be sampled. Within the quadrat frame, the occurrence of plants was recorded using an appropriate measure of abundance. A $15 \mathrm{~m}$ by $15 \mathrm{~m}$ and $50 \mathrm{~cm}$ by $50 \mathrm{~cm}$ quadrats were used for the study. Because a single quadrat cannot be expected to sample a community adequately, repeated quadrat samples were taken. The sampling points were divided up into sub-areas depending on topography and apparent floristic differences; and these were sampled separately; within sub-areas, quadrats were located randomly. This type of sampling approach ensures a representative sample of the different physical and floristic features of the study areas. This type of sampling is called stratified random sampling.

When sampling vegetation using quadrats, different measures of abundance were quantified to assess the influence or "importance" of each species in that quadrat. For example, the following were taken:

Counts - a simple tally of the number of individuals of a species

Cover - the percent (\%) area of the quadrat occupied by a plant species.

Density - estimated by quantifying the number of individuals of a species per unit area.

Frequency - the proportion of quadrats sampled in which the species is represented.

Overall cover, density and frequency estimates were then calculated for each species from the entire data set by combining all of the quadrats together, as indicated in the formula. To determine the proportional representation of each species relative to the entire plant community, relative cover, relative density and relative frequency values can be computed. For example, relative cover is the proportional cover of an individual species as a percentage of total plant cover; hence, it is expressed as a percentage, ranging from 0 $-100 \%$. "Importance" is a measure of overall influence of a plant species in the community. An Importance Value (IV) for each species is derived from the combined contribution of the relative cover, relative density and relative frequency of each species in the community. Because it combines relative cover, density and frequency, importance values range from 0 -300 .

Abundance $(A i)=$ total number of individuals of species $i$

$$
\begin{array}{r}
\text { Cover }(C i)=\text { Total\% cover of species } i \\
\text { Relative cover }(\mathrm{RCi})=\frac{\text { Cover of species } i}{\text { Total plant cover }} \\
\text { Density }(D i)=\frac{A i}{\text { Area }} \\
\text { Relative density }(R D i)=\frac{D i}{\text { Total plant density }}
\end{array}
$$

$$
\text { Frequency }(\mathrm{Fi})=\frac{\text { Number of quadrats with species } i}{\text { Total number of quadrats sampled }}
$$




$$
\text { Relative frequency }(\mathrm{RFi})=\frac{F i}{\text { Total plant frequency }}
$$

Importance value $(I V)=R C i+R D i+R F i$

Note: The IV ranges between 0 - 300

The sampling locations along the study area were chosen at every $10 \mathrm{KM}$ interval from Minna-Bida; the coordinates of the sampling locations are presented in while the habitat type and plant species composition of the study area are presented in 1. The sampling locations were broadly divided into four, i.e. a Hilly-mountainous terrain, a Riparian Vegetation, typical guinea savannah vegetation with similar floristic compositions and a low-land but hilly terrain. Due to the variation in the habitat types as well as soil compositions, there exist high variability in the floristic compositions of the study areas. It was observed that these areas represented typical guinea savannah adequately.

Table 1. Find below the Coordinates of the transect sites along BidaKataeregi-Minna road.

\begin{tabular}{lll}
\hline SITE & Longitude & Latitude \\
\hline A & $09^{\circ} 06^{\prime} 24.2^{\prime \prime}$ & $006^{\circ} 02^{\prime} 06.1^{\prime \prime}$ \\
B & $09^{\circ} 10^{\prime} 26.0^{\prime \prime}$ & $006^{\circ} 05^{\prime} 46.2^{\prime \prime}$ \\
C & $09^{\circ} 14^{\prime} 38.3^{\prime \prime}$ & $006^{\circ} 09^{\prime} 18.2^{\prime \prime}$ \\
D & $09^{\circ} 18^{\prime} 21.0^{\prime \prime}$ & $006^{\circ} 13^{\prime} 22.9^{\prime \prime}$ \\
E & $09^{\circ} 21^{\prime} 41.1^{\prime \prime}$ & $006^{\circ} 17^{\prime} 07^{\prime \prime}$ \\
F & $09^{\circ} 24^{\prime} 12.9^{\prime \prime}$ & $006^{\circ} 22^{\prime} 35.0^{\prime \prime}$ \\
G & $09^{\circ} 33^{\prime} 0.2^{\prime \prime}$ & $006^{\circ} 29^{\prime} 33.3^{\prime \prime}$ \\
H & $09^{\circ} 28^{\prime} 26.3^{\prime \prime}$ & $006^{\circ} 25^{\prime} 46.2^{\prime \prime}$ \\
\hline
\end{tabular}

\section{Results and Discussion}

\subsection{Vegetation Structures and Physiognomy of the Project Areas}

It is not unreal that the variation in plant cover on the global and local scales is mostly determined by the amount of rainfall in such area. Based on the stratification in the falling of rain in Nigeria, for example, the nature of plant cover varies from one area to another, hence given rise to different vegetation zones. The physical structure is one of the most obvious way to describe a forest, and it is important because it can help determine the types of species present. The description of the study areas follow that of Sanford [12]. The vegetation is a typical woodland savannah; both trees and shrubs abound, and the physiognomic classification of this savannah depends on the woody plants.

The general assumption that vegetation in any given savannah zone is homogenous and uniform is not so; progressive movement from Minna through Kateeregi to Bida, revealed that great variations still exit in the vegetations. However, certain trees like Parkia biglobosa (Locust Bean Tree) and Vitellaria paradoxa (Shea Butter Tree) are protected because of their economic importance. The abundance of these plants in number give an unrepresentative picture of the natural vegetation [13].

Study on the vegetation from Minna to Bida showed that, there is an occasional formation of a 'bizzare' floristic composition similar to that of the rain-forest zone. This type of forest is an 'out of phase' formation; it is termed the RIPARIAN forest; such a forest can be observed in the hilly areas, windward directions and stream courses [14]. Such forest can be seen about $7 \mathrm{~km}$ from Bida (N 09 06' 24.2", E $\left.006^{\circ} 02^{\prime} 06.1^{\prime \prime}\right)$.

The trees and shrubs form a canopy, which is generally light; and this seems to be most complex savannah type. The dominant plant species of the herb stratum are the grasses which range in height from $50 \mathrm{~cm}$ to about $250 \mathrm{~cm}$. However, along the Riparian vegetation, there exist taller plants up to $20 \mathrm{~m}$ as well as lianas and palm trees, a typical characteristic of a rain forest belt. Similar observation had been reported by Jibrin and Jaiyeoba [15]. In their opinion riparian forest of the Kpashimi forest reserve of Niger State has comparatively higher mean values of trunk diameter, basal area tree height and crown cover.

Study on vertical structure of the area, when compare with that of forest region is a much less complex vegetation type. The profile shows a tree stratum $8-12 \mathrm{~m}$ high with a generally light canopy. Below this tree stratum is a stratum of shrub also with an irregular canopy, between 3-7 m high. Finally is the herb stratum consisting mainly of members of the Lamiaceae, Acantaceaea and Poaceae, growing up to about $50 \mathrm{~cm}$ to $300 \mathrm{~cm}$ high. Also in the course of this study, it was noted that there are consistent vast destruction of the forests, and different factors responsible for this human influence were identified as need for source of energy, income generation and urbanization.

During the raining season, there exist heterogeneity in the physiognomy and spatial structure of the vegetation of the areas. The most common plants include woody and herbaceous vegetation and grasses was the most dominant during the raining season. It is to be noted that during this season, virtually all the available lands along the road sides are occupied by farmers for planting one crop or the other; the predominant crops being grains like maize, millet, guinea corn, sorghum, sugar cane and few pulses such as, cowpea, groundnut and soy bean as well as yam. During the dry season periods, most of the land are virtually empty, leaving only herbaceous flora that are capable of thriving well during these periods and some trees and shrubs.

\subsection{Floristic Composition, Distribution, Density and Diversity of Vegetation in Minna-Bida}

The vegetation in northern Nigeria is sometimes described as by its tree dominants. It is a typical Savannah woodland, characterised with short trees (between 2-15 m high) and rarely tall trees (over $20 \mathrm{~m}$ high), except at the Riparian vegetation along Minna-Bida road. These communities are agrarian communities where farming, gathering, hunting and fishing are their main occupations. Although, a vast area of land in these communities (communities within the study areas) have been destroyed and degraded by illegal miners, rendering the regions not suitable for agriculture. However, it has been reported that 
biodiversity can only be conserved through vigorous human actions for the preservation of these tree species within their various ecosystems [16]. Clear evidences of individual efforts to resuscitate some parts of the areas through monocropping; plants like palm oil, Eucalyptus, and Tectona grandis (Teak) abound along the road (Figure 1) have been commended.
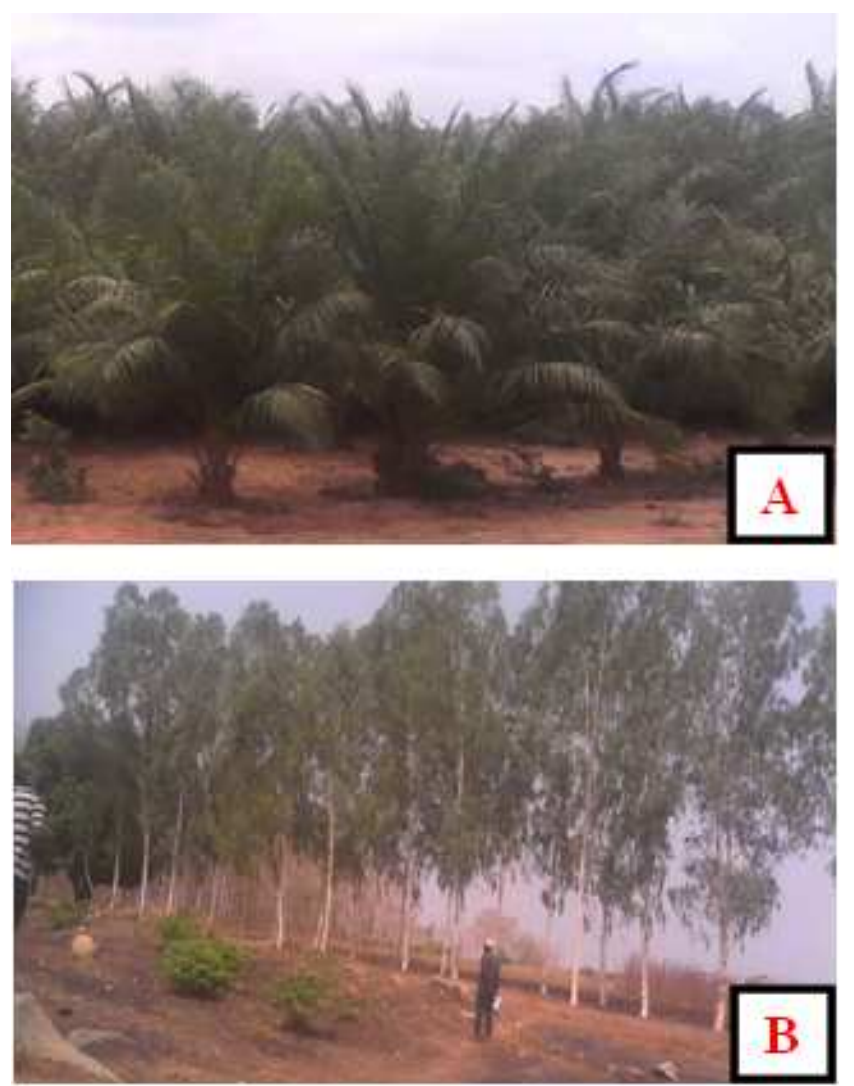

Figure 1. A: Oil Palm Plantation along Minna-Bida Road (N $9^{\circ} 14^{\prime} 49.3 s:$ E $006^{\circ} 9^{\prime} 24.5 s$ ) B: Eucalyptus and Teak Plantation at Garatu Village (Federal University of Technology).

The vegetation is highly degraded and most of the forest encountered are like secondary woodlands where the plants are struggling to regenerate. It was noted that these vegetation had been cleared by members of the community, either for their farmlands or as wood-fuel, as well as ranching. This is evident from numerous hips of firewood encountered during this study (Figure 2).

Classification and distribution of plant species in the study area as well as habitat type and plant species composition in the study area are presented in Table 2 and 3. The tables revealed some interesting information about the plants as well as their compositions. The floristic composition of the project area is highly diverse in species even over a seemingly homogenous area. Where there are changes in the environment, most especially along the mountainous ranges and riparian vegetation, this variation is further increased. This confirmed the statement that, the changes in species distribution and diversity largely depends upon the covered area, association between local and native species diversity while spatial gradients like, elevation, latitude, longitude environmental factors including soil factors and productivity determine diversity pattern [17].

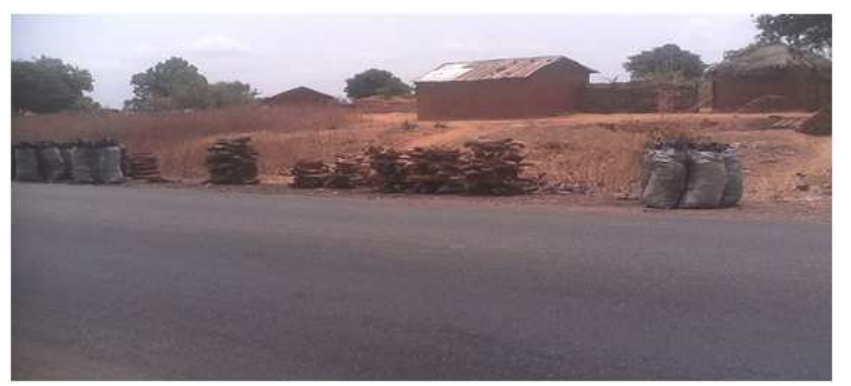

Figure 2 Piles of Firewood and Bags of Charcoal ready for sale at Tsadza Village.

Interestingly, a total of 38 plant species belonging to 21 families were recorded in transects surveyed and comprising of both woody and herbaceous plant species. The species floristic indices of these communities are hereby presented in Table 4. Sixteen (16) species representing about $42 \%$ of the censored species were trees, ten (10) species representing about $26 \%$ are shrubs, whereas, twelve (12) species representing about $32 \%$ were herbs (Figure 3). Most of the herbaceous members encountered are those known to grow in secondary forest, savannah woodlands and disturbed habitats [18]. The result obtained in terms of species abundance, total density, relative cover, relative density, relative frequency as well as the most important species (highest important values) in the study areas and their ranks are presented in Table 4. It is evident from this result that the most abundant species might not necessarily be the most important species. This is so because a lot of factors are considered to obtain the most important values.

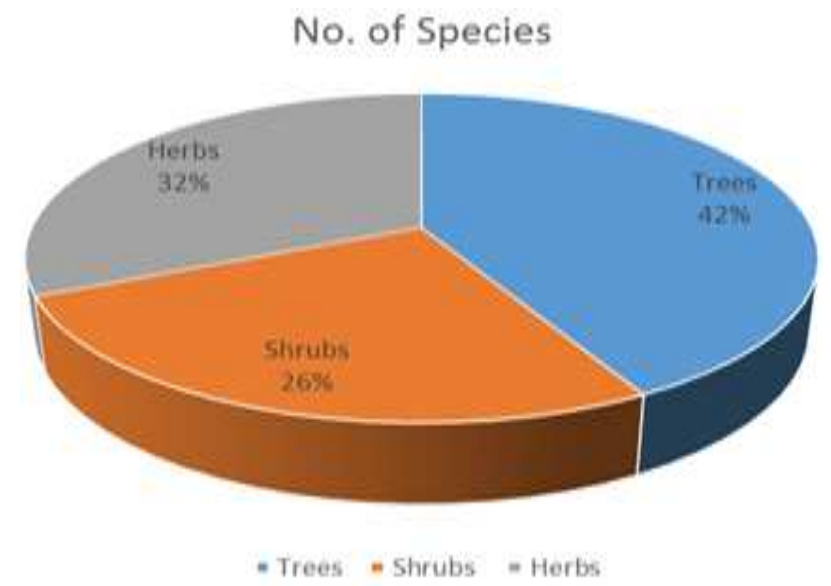

Figure 3. Percentage Composition of the habits of the sampled plant species in Minna-Bida Community. 
Table 2. Classification and Distribution of Plant Species in the Study Area.

\begin{tabular}{|c|c|c|c|c|c|c|c|c|c|c|c|c|}
\hline \multirow{2}{*}{$\mathbf{S} / \mathbf{N}$} & \multirow{2}{*}{ FAMILY } & \multirow{2}{*}{$\begin{array}{l}\text { SPECIES } \\
\text { (Scientific Name) }\end{array}$} & \multirow{2}{*}{ COMMON NAME } & \multirow{2}{*}{ HABIT } & \multicolumn{8}{|c|}{ OCCURRENCE/SITE } \\
\hline & & & & & 1 & 2 & 3 & 4 & 5 & 6 & 7 & 8 \\
\hline 1 & Lamiaceae & Hyptis suaveolens & Curry Leaf & Herb & 39 & 0 & 82 & 151 & 159 & 125 & 71 & 112 \\
\hline 3 & Sapotaceae & Vitellaria paradoxa & Shea butter tree & Tree & 9 & 0 & 4 & 0 & 3 & 6 & 0 & 13 \\
\hline 4 & Anacardiaceae & Mangifera indica & Mango & Tree & 0 & 1 & 0 & 0 & 0 & 0 & 13 & 0 \\
\hline 5 & Asteraceae & Ageratum conyzoides & Goat Weed & Herb & 0 & 0 & 0 & 0 & 0 & 0 & 0 & 160 \\
\hline 6 & Poaceae & Pennisetum sp & Wild Millet & Herb & 13 & 0 & 0 & 0 & 0 & 0 & 11 & 80 \\
\hline 7 & Lentibulariaceae & Utricularia sp & Utricularia & Herb & 0 & 151 & 0 & 0 & 0 & 0 & 0 & 0 \\
\hline 8 & Fabaceae & Piliostigma thonningii & Thonning's piliostigma & Shrub & 5 & 0 & 0 & 3 & 0 & 0 & 20 & 0 \\
\hline 9 & Fabaceae & Dichrostachys cineria & Cow Thorn & Shrub/Tree & 5 & 0 & 0 & 4 & 3 & 0 & 3 & 0 \\
\hline 10 & Annonaceae & Annona senegalensis & Sour Sop & Shrub & 6 & 0 & 1 & 1 & 0 & 0 & 2 & 0 \\
\hline 11 & Combretaceae & Terminalia glaucescens & Muyati, Idi (Yoruba) & Shrub & 2 & 0 & 7 & 0 & 2 & 0 & 0 & 0 \\
\hline 12 & Fabaceae & Senna occidentalis & Coffee Senna & Shrub & 13 & 0 & 0 & 0 & 0 & 0 & 2 & 8 \\
\hline 14 & Arecaceae & Hyphaene thebaica & Dum Palm & Tree & 0 & 1 & 0 & 1 & 0 & 1 & 0 & 0 \\
\hline 15 & Bignoniaceae & Stereospermum kunthianum & Bekele & Shrub & 7 & 0 & 0 & 0 & 2 & 0 & 2 & 5 \\
\hline 16 & Meliaceae & Azadirachta indica & Neem Tree & Tree & 0 & 0 & 0 & 2 & 0 & 6 & 0 & 0 \\
\hline 17 & Rubiaceae & Nauclea latifolia & African Peach & Shrub & 1 & 0 & 0 & 5 & 0 & 0 & 0 & 1 \\
\hline 18 & Poaceae & Hyparrhenia sp & Coolatai grass & Herb & 0 & 23 & 0 & 0 & 0 & 0 & 0 & 0 \\
\hline 19 & Malvaceae & Grewia venusta & Ururu & Herb & 12 & 0 & 0 & 0 & 0 & 0 & 0 & 1 \\
\hline 20 & Fabaceae & Parkia biglobosa & Locust Bean Tree & Tree & 1 & 0 & 1 & 0 & 0 & 0 & 0 & 0 \\
\hline 21 & Poaceae & Imperata cylindrical & Cogon grass & Herb & 0 & 37 & 0 & 0 & 0 & 0 & 0 & 0 \\
\hline 22 & Fabaceae & Afzelia africana & Afzelia & Tree & 9 & 0 & 0 & 0 & 0 & 0 & 0 & 0 \\
\hline 23 & Acanthaceae & Nelsonia canescens & Nelsonia & Herb & 0 & 0 & 0 & 3 & 0 & 0 & 0 & 9 \\
\hline 24 & Malvaceae & Sterculia setigera & Tropical Chestnut & Tree & 0 & 0 & 0 & 2 & 0 & 1 & 0 & 0 \\
\hline 25 & Asparagaceae & Asparagus africanus & Asparagus & Herb & 30 & 0 & 0 & 0 & 0 & 0 & 0 & 0 \\
\hline 26 & Fabaceae & Eriosema psoraleoides & Canary Pea & Shrub & 0 & 0 & 0 & 0 & 1 & 0 & 14 & 0 \\
\hline 29 & Araceae & Amorphophallus dracontoides & Titan Arums & Herb & 0 & 17 & 0 & 0 & 0 & 0 & 0 & 0 \\
\hline 30 & Poaceae & Eragrostis tremula & Love Grass & Herb & 13 & 0 & 0 & 0 & 0 & 0 & 0 & 0 \\
\hline 31 & Lamiaceae & Gmelina arborea & Gmelina & Tree & 0 & 0 & 0 & 0 & 1 & 0 & 0 & 0 \\
\hline 32 & Arecaceae & Elaeis guineensis & Palm Tree & Tree & 0 & 2 & 0 & 0 & 0 & 0 & 0 & 0 \\
\hline 33 & Combretaceae & Anogeissus sp & African Birch & Tree & 0 & 1 & 0 & 0 & 0 & 0 & 0 & 3 \\
\hline 34 & Verbenaceae & Vitex doniana & Black Plum & Tree & 0 & 1 & 0 & 0 & 0 & 0 & 0 & 0 \\
\hline 35 & Fabaceae & Prosopis africana & African mesquite & Tree & 3 & 0 & 0 & 0 & 0 & 0 & 0 & 0 \\
\hline 36 & Fabaceae & Senna sp & Common Senna & Shrub & 0 & 0 & 0 & 0 & 0 & 0 & 0 & 7 \\
\hline 37 & Nymphaeaceae & Nymphaea lotus & Water Lilly & Herb & 0 & 5 & 0 & 0 & 0 & 0 & 0 & 0 \\
\hline 38 & Meliaceae & Khaya senegalensis & Dry Zone Mahogany & Tree & 0 & 0 & 0 & 0 & 0 & 0 & 0 & 2 \\
\hline
\end{tabular}

The five most abundant species across the proposed project areas at the Minna-Bida community include: Hyptis suaveolens (739 individuals), Daniella oliveri (58 individuals), Vitellaria paradoxa (35 individuals), Mangifera indica (14 individuals), and Ageratum conyzoides (160 individuals). However, five of the species that had the least abundance are: Vitex doniana (1 individual), Prosopis africana (3), Senna sp (7 individuals), Nymphaea lotus (5 individuals), Khaya senegalensis (2 individuals) (Table 4). Some of the abundant and least abundant (rare) species are presented in Figure 4. The IUCN status of most of the plant species encountered during the study showed that they can be broadly classified into two conservation status; most of the plants encountered are Data Deficient (DD), were as few of them are Vulnerable (V). Sheanut tree, Utricularia, Afzelia africana, and Mahogany are vulnerable, whereas, most of the other plants are either data deficient or least concerned (Table 4). Mahogany and Afzelia, for example, that have been rated as vulnerable are at the brim of been referred to as threatened, they are very scarce in the study areas. The few that were encountered were somehow protected and conserved along the road sides; probably due to their cultural values and economic importance. This implies that greater mechanism must be put in place to prevent these plants from being extinct locally; any road project of this type must take into cognisance, the conservation of these economically important flora. 
Table 3. Species Floristic Indices of Minna-Bida Vegetation.

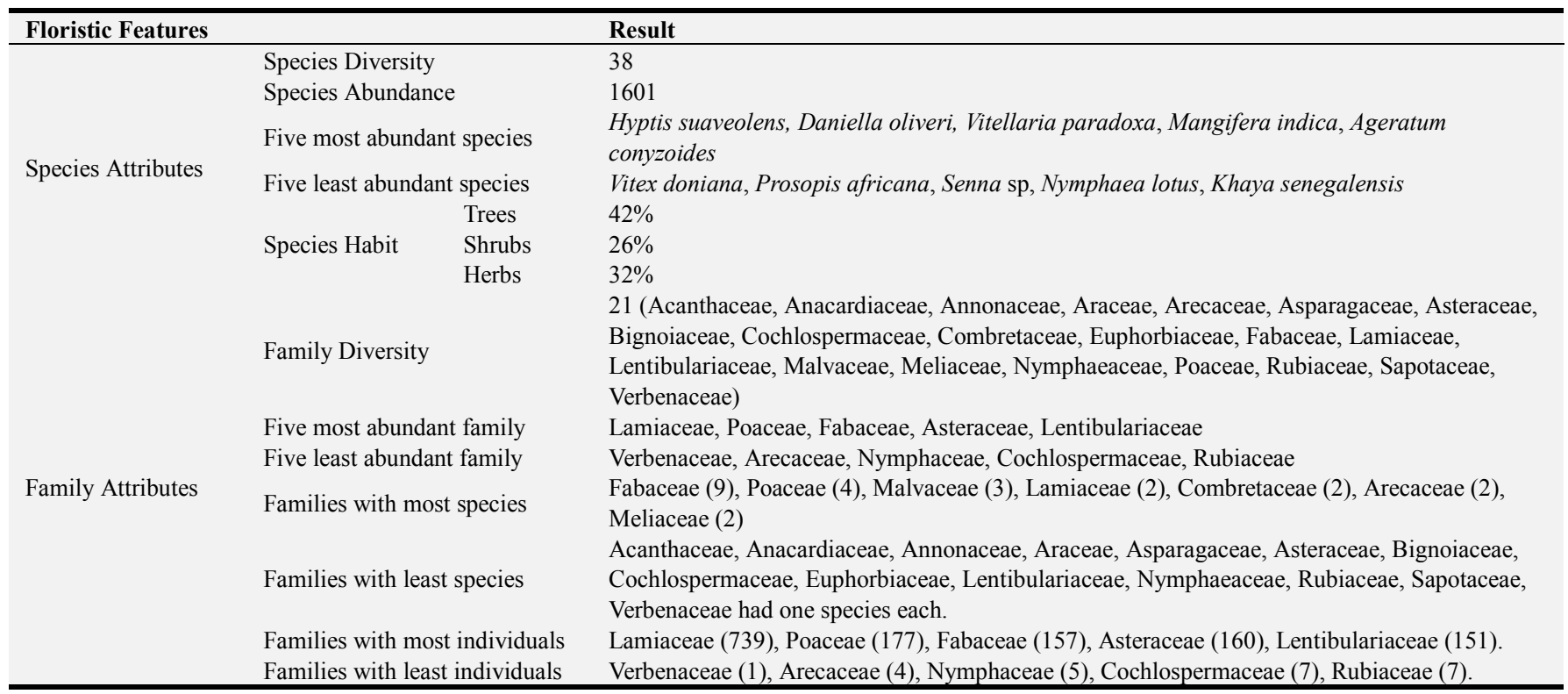

Table 4. Floristic data of Minna-Bida Vegetation.

\begin{tabular}{|c|c|c|c|c|c|}
\hline Species & Common Name & Family & Abundance & IUCN Status & Density \\
\hline Hyptis suaveolens & Curry Leaf & Lamiaceae & 739 & $\mathrm{DD}$ & 4.93 \\
\hline Daniella oliveri & Ilorin Balsam & Fabaceae & 58 & DD & 0.39 \\
\hline Vitellaria paradoxa & Shea butter tree & Sapotaceae & 35 & $\mathrm{~V}$ & 0.23 \\
\hline Mangifera indica & Mango & Anacardiaceae & 14 & DD & 0.09 \\
\hline Ageratum conyzoides & Goat Weed & Asteraceae & 160 & DD & 1.07 \\
\hline Pennisetum sp & Wild Millet & Poaceae & 104 & DD & 0.69 \\
\hline Utricularia $\mathrm{sp}$ & Utricularia & Lentibulariaceae & 151 & V & 1.01 \\
\hline Dichrostachys cineria & Cow Thorn & Fabaceae & 15 & DD & 0.1 \\
\hline Annona senegalensis & Sour Sop & Annonaceae & 10 & DD & 0.07 \\
\hline Terminalia glaucescens & Muyati, Idi (Yoruba) & Combretaceae & 11 & DD & 0.07 \\
\hline Senna occidentalis & Coffee Senna & Fabaceae & 23 & DD & 0.15 \\
\hline Cochleospermum tinctorium & Balagande (Hausa) & Cochlospermaceae & 7 & DD & 0.05 \\
\hline Hyphaene thebaica & Dum Palm & Arecaceae & 3 & DD & 0.02 \\
\hline Stereospermum kunthianum & Bekele & Bignoniaceae & 16 & DD & 0.11 \\
\hline Nauclea latifolia & African Peach & Rubiaceae & 7 & DD & 0.05 \\
\hline Hyparrhnia sp & Coolatai grass & Poaceae & 23 & DD & 0.15 \\
\hline Grewia venusta & Ururu & Malvaceae & 13 & DD & 0.09 \\
\hline Parkia biglobosa & Locust Bean Tree & Fabaceae & 2 & DD & 0.01 \\
\hline Imperata cylindrica & Cogon grass & Poaceae & 37 & DD & 0.25 \\
\hline Afzelia Africana & Afzelia & Fabaceae & 9 & $\mathrm{~V}$ & 0.06 \\
\hline Nelsonia canescens & Nelsonia & Acanthaceae & 12 & DD & 0.08 \\
\hline Sterculia setigera & Tropical Chestnut & Malvaceae & 3 & DD & 0.02 \\
\hline Asparagus africanus & Asparagus & Asparagaceae & 30 & DD & 0.2 \\
\hline Eriosema psoraleoides & Canary Pea & Fabaceae & 15 & DD & 0.1 \\
\hline Alchornea cordifolia & Christmas Bush & Euphorbiaceae & 9 & DD & 0.06 \\
\hline Waltheria indica & Sleepy Morning & Malvaceae & 4 & DD & 0.03 \\
\hline Amorphophallus dracontoides & Titan Arums & Araceae & 17 & DD & 0.11 \\
\hline Eragrostis tremula & Love Grass & Poaceae & 13 & DD & 0.09 \\
\hline Gmelina arborea & Gmelina & Lamiaceae & 1 & DD & 0.01 \\
\hline Borassus aethiopium & Palm Tree & Arecaceae & 1 & DD & 0.01 \\
\hline Prosopis Africana & African mesquite & Fabaceae & 3 & DD & 0.02 \\
\hline Senna sp & Common Senna & Fabaceae & 7 & DD & 0.05 \\
\hline Nymphaea lotus & Water Lilly & Nymphaeaceae & 5 & DD & 0.03 \\
\hline Khaya senegalensis & Dry Zone Mahogany & Meliaceae & 2 & V & 0.01 \\
\hline TOTAL & & & 1601 & & 10.7 \\
\hline
\end{tabular}


Table 4. Continued.

\begin{tabular}{|c|c|c|c|c|c|c|}
\hline Species & Frequency & Relative Cover & Relative Density & Relative Frequency & Importance Value & Rank \\
\hline Hyptis suaveolens & 0.75 & 15.1 & 46.2 & 8.11 & 69.3 & 1 \\
\hline Daniella oliveri & 0.5 & 19.6 & 3.62 & 5.41 & 28.7 & 2 \\
\hline Vitellaria paradoxa & 0.5 & 20.7 & 2.19 & 5.41 & 28.3 & 3 \\
\hline Mangifera indica & 0.25 & 11.4 & 0.87 & 2.7 & 15 & 4 \\
\hline Ageratum conyzoides & 0.13 & 1.63 & 9.99 & 1.35 & 13 & 5 \\
\hline Pennisetum $\mathrm{sp}$ & 0.38 & 0.98 & 6.5 & 4.05 & 11.5 & 6 \\
\hline Utricularia sp & 0.13 & 0.16 & 9.43 & 1.35 & 11 & 7 \\
\hline Dichrostachys cineria & 0.38 & 3.05 & 0.94 & 4.05 & 8.05 & 9 \\
\hline Annona senegalensis & 0.5 & 0.81 & 0.62 & 5.41 & 6.84 & 10 \\
\hline Terminalia glaucescens & 0.38 & 1.47 & 0.69 & 4.05 & 6.21 & 11 \\
\hline Senna occidentalis & 0.38 & 0.24 & 1.44 & 4.05 & 5.74 & 12 \\
\hline Cochleospermum tinctorium & 0.38 & 0.73 & 0.44 & 4.05 & 5.22 & 13 \\
\hline Hyphaene thebaica & 0.25 & 2.04 & 0.19 & 2.7 & 4.93 & 14 \\
\hline Stereospermum kunthianum & 0.25 & 1.08 & 1 & 2.7 & 4.79 & 15 \\
\hline Hyparrhnia sp & 0.13 & 1.55 & 1.44 & 1.35 & 4.34 & 18 \\
\hline Grewia venusta & 0.25 & 0.66 & 0.81 & 2.7 & 4.17 & 19 \\
\hline Parkia biglobosa & 0.25 & 1.22 & 0.12 & 2.7 & 4.05 & 20 \\
\hline Imperata cylindrical & 0.13 & 0.17 & 2.31 & 1.35 & 3.83 & 21 \\
\hline Afzelia Africana & 0.13 & 1.83 & 0.56 & 1.35 & 3.75 & 22 \\
\hline Nelsonia canescens & 0.25 & 0.16 & 0.75 & 2.7 & 3.62 & 23 \\
\hline Sterculia setigera & 0.25 & 0.65 & 0.19 & 2.7 & 3.54 & 24 \\
\hline Asparagus africanus & 0.13 & 0.2 & 1.87 & 1.35 & 3.43 & 25 \\
\hline Eriosema psoraleoides & 0.13 & 1.02 & 0.94 & 1.35 & 3.31 & 26 \\
\hline Alchornea cordifolia & 0.13 & 1.22 & 0.56 & 1.35 & 3.14 & 27 \\
\hline Waltheria indica & 0.25 & 0.16 & 0.25 & 2.7 & 3.12 & 28 \\
\hline Amorphophallus dracontoides & 0.13 & 0.35 & 1.06 & 1.35 & 2.76 & 29 \\
\hline Eragrostis tremula & 0.13 & 0.15 & 0.81 & 1.35 & 2.31 & 30 \\
\hline Gmelina arborea & 0.13 & 0.81 & 0.06 & 1.35 & 2.23 & 31 \\
\hline Borassus aethiopium & 0.13 & 0.68 & 0.06 & 1.35 & 2.09 & 32 \\
\hline Prosopis Africana & 0.13 & 0.41 & 0.19 & 1.35 & 1.95 & 35 \\
\hline Senna $\mathrm{sp}$ & 0.13 & 0.15 & 0.44 & 1.35 & 1.94 & 36 \\
\hline Nymphaea lotus & 0.13 & 0.24 & 0.31 & 1.35 & 1.91 & 37 \\
\hline Khaya senegalensis & 0.13 & 0.2 & 0.12 & 1.35 & 1.68 & 38 \\
\hline TOTAL & 9.25 & 100 & 100 & 100 & 300 & \\
\hline
\end{tabular}

Conservation status of plant species encountered: V (Vulnerable), T (Threatened), DD (Data deficient), LC (Least concerned)
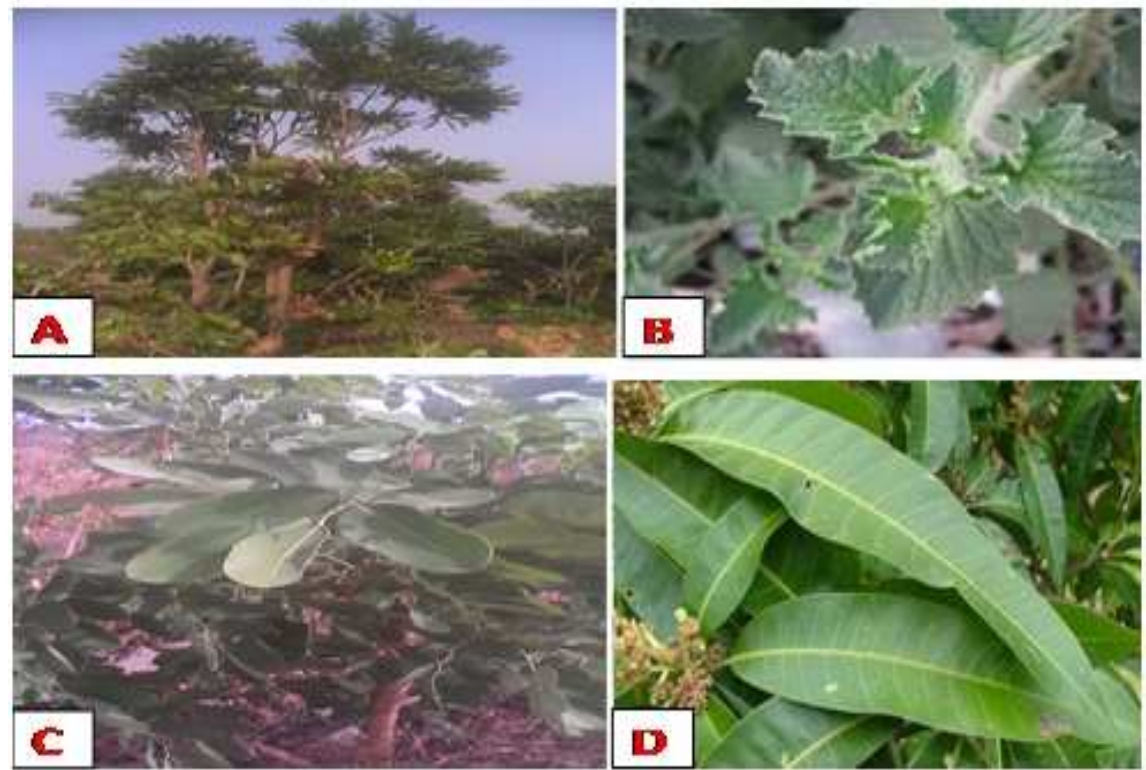

Figure 4a. Most abundant species in Minna-Bida Vegetation Study (A: Vitellaria paradoxa B: Hyptis suaveolens C: Daniellia oliveri D: Mangifera indica. 

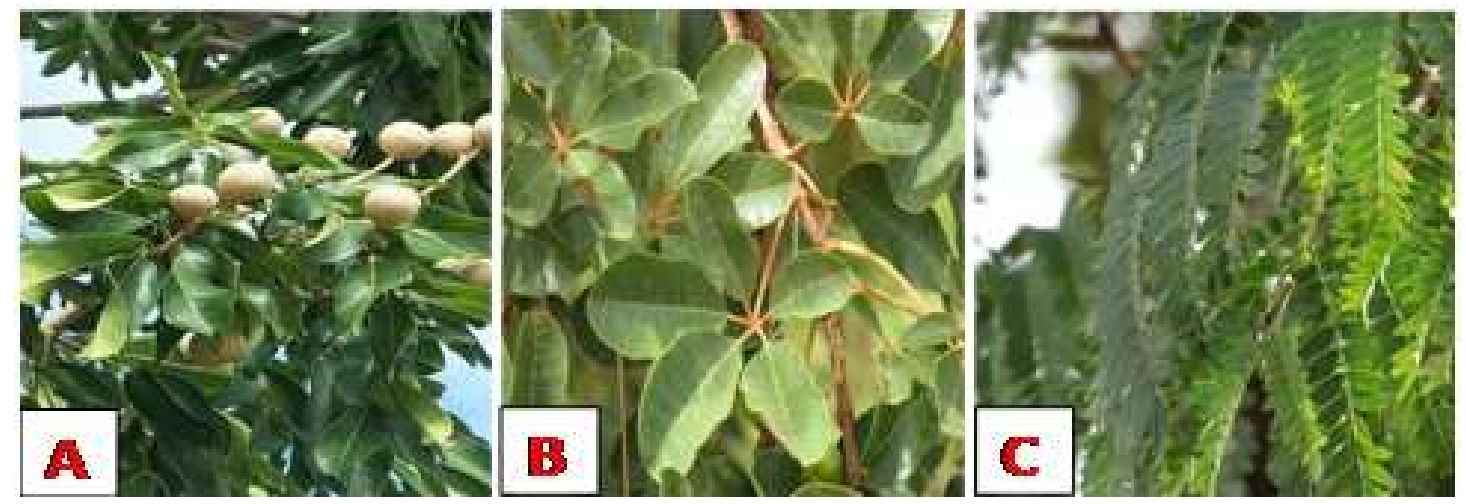

Figure 4b. Least abundant species in Gaffar community project site (A: Khaya senegalensis B: Vitex doniana C: Prosopis africana).

The family that has the highest number of species (9) i.e. most frequent family is Fabaceae. This is followed by Poaceae (4 species), then Malvaceae (3); Lamiaceae, Combretaceae, Arecaceae and Meliaceae had two species each. Acanthaceae, Anacardiaceae, Annonaceae, Araceae, Asparagaceae, Asteraceae, Bignoiaceae, Cochlospermaceae, Euphorbiaceae, Lentibulariaceae, Nymphaeaceae, Rubiaceae,
Sapotaceae and Verbenaceae are represented by one species each (Table 1). Interestingly, the family with the highest individuals is the Lamiaceae (739, this is followed by Poaceae (177) then Asteraceae (160), Fabaceae (160) and Lentibulariaceae (151). The families with the lowest number of species are Verbenaceae (1), Arecaceae (4), Nymphaceae (5), Cochlospermaceae (7) and Rubiaceae (7) (Figure 5).

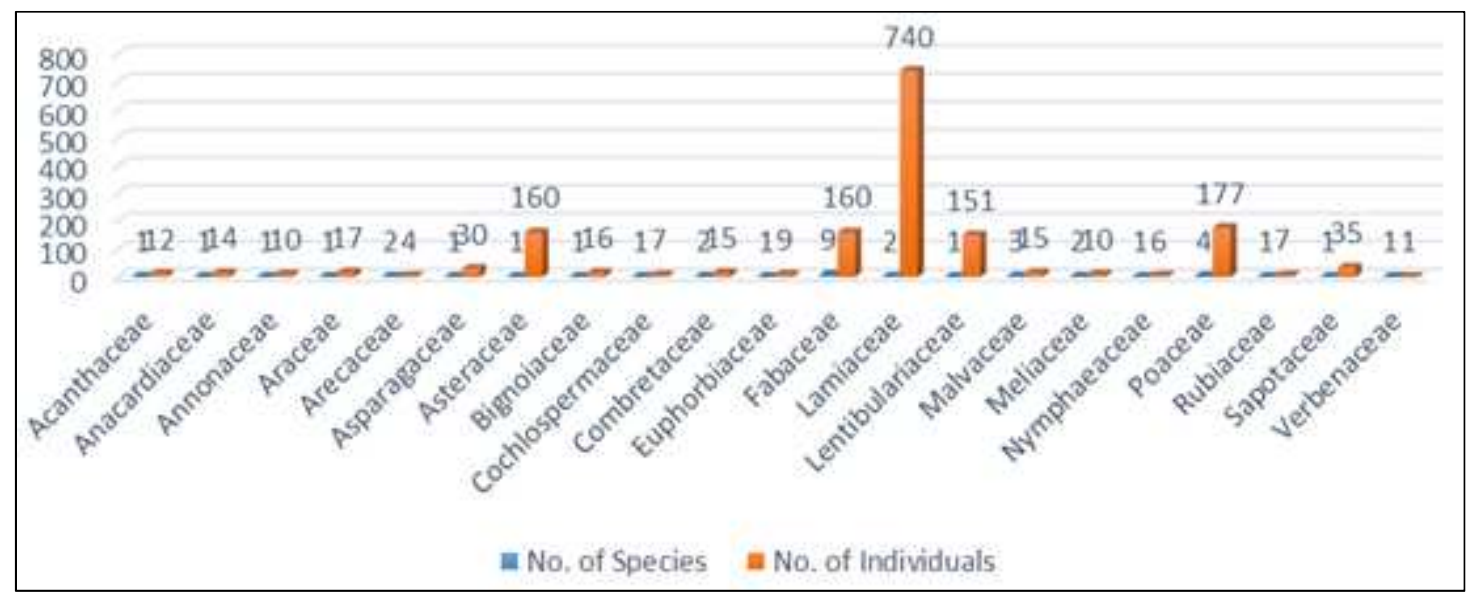

Figure 5. Family abundance of the plants encountered along Minna-Bida Vegetation zone.

\section{Conclusion}

It is therefore concluded that Minna-Bida road represents a typical guinea savannah due to the composition of plants encountered. The floristic composition of the project area is highly diverse in species even over a seemingly homogenous area. Where there are changes in the environment, most especially along the mountainous ranges and riparian vegetation, this variation is further increased. Interestingly, a total of 38 plant species belonging to 21 families were recorded in transects surveyed and comprising of both woody and herbaceous plant species.

\section{Acknowledgements}

We would like to express our gratitude to the Global Environmental Help Solution for providing us technical and materials supports for the realization of this work.

\section{References}

[1] S. R. Levick, G. P. Asner, T. Kennedy-Bowdoin, and D. E. Knapp, "The relative influence of fire and herbivory on savannah three dimensional vegetation structure. Biological Conservation," 2009; vol. 142, pp. 1693-1700.

[2] G. Sarmiento, "The ecology of neotropical savannahs. Cambridge: Harvard University Press," 1984.

[3] G. J. Martin, "Ethnobotany: A method manual. Botanic Garden, Kew. UK: Chapman and Hall press.” 1996.

[4] M. Sankaran, N. P. Hanan, R. J. Scholes, and J. Ratnam, "Determinants of woody cover in African savannah," Nature, vol. 438(7069), pp. 846-849.

[5] C. Giri, Z. Zhu, and B. Reed, "A comparative analysis of the Global L and Cover 2000 and MODIS land cover data sets," Remote Sensing of Environment," 2005, vol. 94(1), pp. 123132. 
[6] Privette, J. L., Tian, Y., Roberts, G., and Scholes, R. J., (2004). Vegetation structure characteristics and relationships of Kalahari woodlands and savannahs. Global Change Biology, 10, pp. 281-291.

[7] L. E. Herber, "The Natural History of Trees" Nicolson Oxford University Press, Ibadan, 1976, pp 1.

[8] Food and Agricultural Organization [FAO], "Global Forest Resources Assessment: 2000 Main Report F. A. O Forestry paper, 140 F. A. O, Rome, 2001.

[9] W. W. Sanford, and A. O. Isichei, "Savannah. In G. W. Lawson (ed.), Plant ecology in West Africa: systems and processes Chichester: John Wiley \& Sons," 1986, pp. 95-150.

[10] N. Sokpon, T. Sinadouwirou, F. Gbaguidi, and S. H. Biaou, "Survey of the wetland forests of Benin. Belgian Journal of Botany," 2001, vol. 134, pp. 79-93.

[11] A. D. Bradshaw, and M. J. Chadwick, "The restoration of land. University of California Press, Berkeley, Calif,” 1980.

[12] W. W. Sanford, "Effects of Seasonal burning on Nigerian Savanna. Proceed MAB State of Knowledge Workshop on Nigerian Savanna, Kainji, Nigeria,” 1980.
[13] G. W. Lawson, "Plant Life in West Africa. Oxford University Press, London," 1966, pp. 28-44.

[14] Scottish Environmental Protection Agency, "Engineering in the Water Environment Good Practice Guide: Riparian Vegetation Management," 2009, pp 1-47.

[15] A. Jibrin, and I. A. Jaiyeoba, "Characterization of Structural Composition and Diversity of Vegetation in the Kpashimi Forest Reserve, Niger State, Nigeria," Journal of Geography and Geology, 2013, vol. 5(3), pp. 75-87.

[16] A. D. Agbelade, and O. A. Fagbemigun, "Assessment of Incentives for Forest Biodiversity Conservation in Rainforest and Derived Savannah Vegetation Zones of Ekiti State, Nigeria," Forest Research, 2015, vol. 4(3), 1000150.

[17] M. Zahid, K. Nasrullah, A. Shaukat, U. Atta, M. K. Shahid, "Density and Taxonomic Diversity of Understory Vegetation in Relation to Site Conditions in Natural Stands of Acacia modesta in Malakand Division, Khyber Pakhtunkhwa, Pakistan," Science, Technology and Development, 2016, vol. 35(1), pp. 26-34.

[18] T. F. Daniel, "Catalog of Acanthaceae in El Salvador. Contributions from the University of Michigan Herbarium," 2001, vol. 23, pp. 115-137. 